\title{
VERSCHILLEN TUSSEN BURGERS IN VERTROUWEN IN DE RECHTSPRAAK
}

\section{Bert Niemeijer en Peter van Wijck}

\section{INLEIDING}

Het vertrouwen van burgers in de rechtspraak staat ter discussie, vooral in de media en de politiek. Het beeld van de rechtspraak is niet best. Vooral de strafrechtspraak komt keer op keer negatief in het nieuws. Er is regelmatig ophef over te lage straffen, over rechterlijke dwalingen en over wraking van rechters. Politici uiten zich regelmatig negatief over de rechtspraak.

In deze context zou men verwachten dat burgers niet al te veel vertrouwen in de rechtspraak hebben. Dit blijkt echter maar ten dele het geval. Het percentage van de bevolking dat "voldoende vertrouwen" in de rechtspraak heeft, schommelde de laatste jaren ruwweg tussen de 60 en 70\%. ${ }^{1}$ In vergelijking met andere landen scoort Nederland hoog. ${ }^{2}$ Toch is het beeld minder positief dan het op het eerste gezicht lijkt. Een redelijk omvangrijke groep (ca. een zesde deel) heeft geheel geen vertrouwen in de rechtspraak. De mate van vertrouwen hangt samen met specifieke kenmerken. Mannen, lager opgeleiden, ouderen en sympathiserenden met niet gevestigde politieke partijen hebben gemiddeld minder vertrouwen. ${ }^{3}$ Dit wijst erop dat de bevolking te heterogeen is om te spreken over "het" vertrouwen van "de" burger in de rechtspraak.

In dit artikel nemen we de heterogeniteit van de bevolking als vertrekpunt. De samenleving bestaat uit verschillende groepen mensen, groepen die ook uiteenlopen in hun vertrouwen in de rechtspraak. Vanwege deze heterogeniteit, kunnen maatregelen gericht op het versterken van vertrouwen bij uiteenlopende groepen verschillend uitwerken. We richten ons op de vraag waar aangrijpingspunten liggen voor het versterken van vertrouwen in de rechtspraak. In hoeverre verschillen de aangrijpingspunten voor uiteenlopende groepen?

Dit artikel is als volgt opgebouwd. In paragraaf 2 gaan we nader in op vertrouwen. In paragraaf 3 schetsen we het framingconcept. De kerngedachte is dat signalen over de rechtspraak betekenis krijgen door de frames, interpretatiekaders, die mensen hanteren. We zijn vooral geïnteresseerd in de vraag welk inzicht we krijgen door vanuit framingperspectief naar vertrouwen in de rechtspraak kijken. In paragraaf 4 schetsen we, gebaseerd op focusgroeponderzoek, contrasterende frames. Bovendien kijken we naar de vraag wat hieruit valt te leren voor beleidsmakers die op zoek zijn naar mogelijkheden om vertrouwen in de rechtspraak te vergroten.

\footnotetext{
$1 \quad$ Dekker \& Posthumus 2013. Mensen is de volgende vraag gesteld: 'Hoeveel vertrouwen heeft u op dit moment in de volgende instellingen in Nederland?'. "Voldoende vertrouwen" is geoperationaliseerd als scores 610 op een schaal van 1 (geen enkel vertrouwen) tot 10 (alle vertrouwen).

2 In vergelijking met andere Europese landen hebben in Nederland relatief veel mensen $(65 \%)$ vertrouwen in 'the legal system'. Alleen de Scandinavische landen en Oostenrijk scoren beter. België scoort met $36 \%$ flink lager. (Eurobarometer 2010.11).

$3 \quad$ Aanhangers van de PVV vertrouwen de rechterlijke macht het minst vaak. 44\% van de PVV'ers heeft voldoende vertrouwen in de rechtspraak. Bij alle andere partijen ligt dit percentage ruim boven de 70 . Bij D66/GL heeft zelfs 90\% vertrouwen. Jongeren en hoger opgeleiden hebben vaker vertrouwen in de rechtspraak dan ouderen en lager opgeleiden. Den Ridder e.a. 2011; Zie recent ook Achterberg \& Mascini 2013.
} 


\section{VERTROUWEN IN DE RECHTSPRAAK}

\subsection{Wat is vertrouwen?}

In de literatuur zijn vele definities van 'vertrouwen' te vinden. In een recent artikel over vertrouwen in de rechtspraak volgen Van de Bos en Brenninkmeijer de definitie van Sztompka: "vertrouwen is de overtuiging dan andere personen of instituties ons niet met opzet kwaad zullen aandoen, zeker niets als ze dit kunnen vermijden, en dat de het goede met ons voorhebben en, indien mogelijk, oog zullen hebben voor onze belangen'. ${ }^{4}$ In deze omschrijving komen zowel personen als instituties voor. Om dit verschil te benadrukken, is het nuttig onderscheid te maken tussen 'sociaal vertrouwen' en 'institutioneel vertrouwen'. Toegespitst op vertrouwen in de rechtspraak, verwijst sociaal vertrouwen naar de mate waarin burgers vertrouwen hebben in personen die een rol vervullen binnen de rechtspraak. Daarbij valt in de eerste plaats te denken aan rechters. Institutioneel vertrouwen verwijst juist naar de mate waarin burgers erop vertrouwen dat het systeem naar behoren functioneert.

\subsection{Het belang van vertrouwen}

Vertrouwen is van cruciaal belang, voor de rechtspraak en voor de gehele Nederlandse samenleving. Volgens Fukuyama is de mate van sociaal en institutioneel vertrouwen in een samenleving bepalend voor de kwaliteit ervan. ${ }^{6}$ Individuen in een 'high-trust' samenleving hebben ook sterke relaties buiten de eigen familie of sociale groep. Daardoor durven zij ook buiten eigen kring transacties aan te gaan en dit leidt tot voorspoed op economisch en allerlei andere terreinen. Mensen in een 'low-trust' samenleving zijn daarentegen geneigd mensen buiten de eigen familie of clan te wantrouwen, met geringe (economische) ontwikkeling als gevolg. Vertrouwen alleen is echter niet genoeg om tot voorspoedige ontwikkeling van de samenleving te leiden. Daarvoor zijn tevens instituties nodig, zoals een goed functionerende rechtspraak en adequate handhaving waarin burgers vertrouwen hebben. ${ }^{7}$ Burgers gaan betrekkingen en transacties met andere burgers immers alleen aan, als zij er op vertrouwen dat zij, als het misloopt, uiteindelijk bij de rechter terecht kunnen om hun recht te halen. Zij zullen dan zelf ook meer geneigd zijn regels na te leven. Voor het functioneren van de samenleving is het daarom cruciaal dat burgers kunnen vertrouwen op de rechtspraak.

\subsection{Variatie in vertrouwen}

De samenleving is te heterogeen om te kunnen spreken van het vertrouwen van de burger in de rechtspraak. ${ }^{8}$ Zo zagen we hiervoor al dat sommigen vertrouwen hebben in de rechtspraak, anderen neutraal zijn en weer andere uitgesproken wantrouwend. Dit doet de vraag rijzen of groepen die verschillen in de mate van vertrouwen ook op andere kenmerken verschillen. Zo lieten Mascini en Achterberg recent zien dat burgers die de rechtspraak wantrouwen doorgaans ook andere instituties wantrouwen en specifieke kenmerken hebben. ${ }^{9}$ Voor een goed begrip van de werking van vertrouwen is het essentieel met verschillen tussen burgers

Sztompka 1999; Van den Bos 2011, p 6-7; Van den Bos \& Brenninkmeijer 2012.

In navolging van Luhman 1979 wordt vaak onderscheid gemaakt tussen 'trust' en 'confidence'. Bij 'trust' gaat het om vertrouwen in een andere personen. 'Confidence' verwijst naar vertrouwen $o p$ institities of systemen.

Fukuyama 1995.

Van Velthoven 2005; Beugelsdijk 2006.

Om deze variatie tot uitdrukking te brengen, bestaan tal van typologieën van burgers. Bijv. Van der Meer 2007; Dekker e.a. 2008; WRR 2002; Hertogh 2011; Van den Brink 2008.

$9 \quad$ Achterberg \& Mascini 2013 
rekening te houden. Die verschillen kunnen niet alleen betrekking hebben op de mate van vertrouwen maar ook op de factoren die het vertrouwen beïnvloeden.

\subsection{Waar komt vertrouwen vandaan?}

Er bestaan verschillende theorieën over hoe vertrouwen tot stand komt. Binnen de rechtspraak lijkt vooral het idee te bestaan dat vertrouwen in de rechtspraak groeit als de rechtspraak zijn werk goed doet en verdwijnt als het dit niet doet. Een belangrijk aspect daarvan is procedurele rechtvaardigheid. ${ }^{10}$ Dit idee gaat echter uit van de veronderstelling dat de rechtspraak transparant is en dat burgers (deelnemers en niet-deelnemers) daarover goed zijn geïnformeerd en voorts dat burgers deze informatie op dezelfde wijze waarderen. Beide veronderstellingen lijken niet erg waarschijnlijk. ${ }^{11}$

Hier vertrekken wij vanuit de gedachte dat vertrouwen in de rechtspraak afhankelijk is van signalen over de rechtspraak die burgers op een of andere wijze bereiken. ${ }^{12}$ Die signalen krijgen betekenis door het interpretatiekader van degenen die de signalen ontvangen. Dat is de kern van het, in de inleiding genoemde, framingperspectief. Frames zijn, in de woorden van Lakoff, "mental structures that shape the way we see the world." ${ }^{13}$ De gedachte is dat mensen die uiteenlopende frames hanteren, de wereld op uiteenlopende wijze zien en beoordelen. Bezien vanuit dit perspectief, kunnen frames medebepalend zijn voor het antwoord op de vraag of bepaalde gedragingen, uitingen of regels al dan niet bijdragen aan vertrouwen.

\section{BURGERFRAMES ALS TESTCONDITIES VOOR BELEID}

\subsection{Frames: concept}

Aan de term "framing" worden nogal uiteenlopende betekenissen toegekend. Vaak wordt framing gebruikt in de betekenis van retorisch instrument. Door een maatschappelijk probleem handig "te framen" is het mogelijk een bepaalde betekenis op te roepen, om daarmee steun te verwerven voor het eigen standpunt. In deze betekenis is framing een retorisch instrument in een politiek debat. Hans de Bruijn heeft bijvoorbeeld laten zien hoe Geert Wilders dat doet. ${ }^{14}$ Wie in het frame van een ander stapt, staat in het debat onmiddellijk op achterstand.

Bij framing gaat het echter om meer dan communicatie. De literatuur over framing is omvangrijk. ${ }^{15}$ Het klassieke werk over framing is Frame Analysis van Erving Goffman. ${ }^{16}$ Hij omschrijft daarin een frame als 'a scheme of interpretation in which the particulars of the events and activities to which we attend are organized and made sensible. Frames lead people to notice particular aspects of an interaction, event or phenomenon at a subconscious level, which shapes how they interpret what is around them'. Hij gaat ook in op gebeurtenissen of ontwikkelingen die maken dat een bepaald frame geactiveerd wordt.

\footnotetext{
$10 \quad$ Thibaut \& Walker 1975; Tyler 1990; Brenninkmeijer, Van den Bos \& Röell 2012.

Over transparantie en rechtspraak zie recent Broeders c.s. (red.) 2013.

Van den Bos 2011; Van den Bos \& Brenninkmeijer 2012, p. 1454 e.v.

Lakoff 2004, p. XV.

De Bruin 2010. Zie ook De Bruin 2011.

Zie voor een overzicht: Benford \& Snow 2000 en Chong \& Druckman 2007.

Goffman 1974.
} 
In dit artikel gebruiken we frame in de betekenis van interpretatiekader. Dat kader is mede bepalend voor de wijze waarop maatschappelijke verschijnselen worden waargenomen. Een frame is, met andere woorden, mede bepalend:

1. Voor hetgeen als probleem wordt gezien,

2. Voor de oorzaken waaraan die problemen worden toegeschreven,

3. Voor wat als passende instrumenten wordt gezien om die problemen aan te pakken.

Frames kennen een zekere bestendigheid, of - misschien beter - een hoge mate van starheid. Een frame verandert niet snel, ook niet indien er feiten zijn die niet "passen" in een frame. Of, zoals Lakoff het uitdrukt. "When the facts don't fit the frames, the frames are kept and the facts ignored". ${ }^{17}$

Voor ons doel is van belang dat mensen die uiteenlopende frames hanteren, de wereld verschillend "zien". Meer specifiek: ze zien verschillende problemen, ze schrijven problemen toe aan verschillende oorzaken of ze denken verschillend over de effectiviteit van instrumenten.

\subsection{Reacties van burgers op beleid}

Door vanuit het perspectief van frames te kijken, kunnen we zicht krijgen op reacties van burgers op beleid. De gedachte daarbij is, dat mensen die uiteenlopende frames hanteren, ook verschillend op beleid zullen reageren.

Het feit dat burgers uiteenlopende frames hanteren, stelt beleidsmakers voor lastige vragen. Het kan zo zijn dat maatregelen bij uiteenlopende groepen tot verschillende (gedrags)reacties leiden. Gegeven de drie onderscheiden dimensies, kunnen (verbale) reacties betrekking hebben op problemen, oorzaken en instrumenten: "Ze pakken de verkeerde problemen aan", "ze snappen niet waardoor de problemen ontstaan" of "ze nemen maatregelen waarvan iedereen weet dat ze niet werken".

Om zo goed mogelijk rekening te houden met uiteenlopende burgerframes, kunnen beleidsmakers de volgende vier stappen zetten.

1. Inventariseer welke instrumenten (volgens beleidsframe) geschikt kunnen zijn om probleem aan te pakken.

Deze eerste stap leidt tot een verzameling potentiële instrumenten. Idealiter vloeien ze voort uit een gevalideerde (beleids)theorie. Die theorie legt een verband tussen op te lossen problemen, oorzaken van die problemen en instrumenten die bij die oorzaken aangrijpen. In werkelijkheid gaat het vaak om een verzameling te toetsen potentiële instrumenten.

2. Breng verschillende burgerframes in beeld.

De tweede stap leidt tot een verzameling uiteenlopende burgerframes. Bij die frames gaat het om de interpretatiekaders die burgers erop nahouden. Interpretatiekaders die medebepalend zijn voor wat mensen als problemen zien, de oorzaken waaraan ze die problemen toeschrijven en instrumenten die ze geschikt achten.

\footnotetext{
17 Lakoff 2004, p. 73. Lakoff betoogt dat frames samenhangen met de waarden van de waarnemer. Zo nemen republikeinen en democraten in de VS de wereld op sterk uiteenlopende wijze waar. De frames van republikeinen en democraten duidt hij aan als "strict father model" resp. "nurturant parent model". Zie Lakoff 2004, p. 6; Lakoff 2008, p. 77; Lakoff \& Wehling 2012, pp. 29-34.
} 
3. Test hoe instrumenten uitwerken in de verschillende burgerframes.

De derde stap leidt tot inzicht in de vraag hoe instrumenten uitwerken bij uiteenlopende groepen. Hierbij worden instrumenten getoetst aan uiteenlopende burgerframes, een procedure die bekend staat als "windtunnelen". ${ }^{18}$

Voor verschillende beleidsopties wordt nagegaan hoe ze in verschillende frames uitwerken. Werken ze in alle frames goed, of is dat frame-afhankelijk? De uitkomst van de test in de windtunnel, kan van belang zijn voor het antwoord op de vraag of zo'n maatregel moet worden genomen. Onderstaande tabel illustreert de redenering. Daarbij kijken we hoe vier denkbeeldige beleidsopties uitwerken in twee verschillende frames.

\begin{tabular}{|c|c|c|}
\hline Maatregel & In frame A & In frame B \\
\hline Optie 1 & + & + \\
\hline Optie 2 & + & - \\
\hline Optie 3 & - & + \\
\hline Optie 4 & - & - \\
\hline
\end{tabular}

Optie 1 wordt in alle frames goed ontvangen. In die zin bestaat er draagvlak voor de desbetreffende optie. Deze optie is zo bezien 'robuust'. Optie 2 wordt in frame A goed ontvangen maar stuit in frame B op weerstand. Optie 3 stuit in frame A op weerstand maar wordt in frame B goed ontvangen. Optie 4 valt in beide frames slecht.

4. Beredeneer op basis van de voorgaande stappen hoe zo goed mogelijk ingespeeld kan worden op verschillende burgerframes.

Deze laatste stap betreft de selectie van geschikte instrumenten. Immers, de derde stap levert inzicht in de vraag hoe instrumenten uitwerken in verschillende burgerframes. Maar dat geeft nog geen antwoord op de vraag wat nu "de beste" selectie van instrumenten is. Bij de selectie van instrumenten kan een beslisser verschillende strategieën volgen: ${ }^{19}$

- Een "robuuste strategie" is gericht op het selecteren van instrumenten die in alle frames goed werken.

- Een strategie van "op meerder paarden wedden" komt neer op het zoeken van een maatregelenpakket dat in alle frames "redelijk werkt".

- Inzetten op een van de frames, bijvoorbeeld in de hoop of verwachting dat dat frame maatschappelijk dominant wordt.

Bij de geschetste strategieën kiest een beslisser dus niet noodzakelijkerwijs voor de inzet van instrumenten die volgens het "eigen" frame de beste keuze zijn. Een vergelijkbare conclusie is eerder getrokken door Letterie en Swank. ${ }^{20} \mathrm{Zij}$ laten zien dat politici er belang bij kunnen hebben om beleid te baseren op een model dat aansluit bij kiezersvoorkeuren, ook al weten ze dat het een incorrect model is.

\footnotetext{
18 Windtunneling is een aan de literatuur over scenarioplanning ontleend concept. Scenario's worden daarbij opgevat als testcondities in een windtunnel. Bezien wordt dan hoe de verschillende beleidsopties zich houden onder verschillende testcondities. Gedraagt een optie zich onder alle condities goed of is dat scenarioafhankelijk? Hier gebeurt iets analoogs. Zie bijvoorbeeld Scearce \& Fulton 2004 of Van der Heijden 2005, p. 283.

19 Dit naar analogie van de literatuur over scenarioplanning. Zie bijvoorbeeld De Ruijter, Stolk \& Alkema 2011 of Nekkers 2007.

$20 \quad$ Letterie \& Swank 1998.
} 
Figuur 1 vat de redenering samen. Al dan niet op basis van een expliciete beleidstheorie (een beleidsframe) selecteren beleidsmakers potentiële instrumenten. Hoe die instrumenten uitwerken, hangt af van de frames die burgers hanteren. Burgerframes zijn bepalend voor de gedragsreacties en de oordelen van burgers. Beleidsmakers staan voor de vraag hoe daar mee om te gaan. De linker terugkoppeling verwijst naar de inhoudelijke selectie van instrumenten. De rechter terugkoppeling verwijst naar de communicatiestrategie. Die heeft deels te maken met de wijze waarop de instrumenten worden neergezet. Ook kan worden gedacht aan "framing" in de zin van het beïnvloeden van burgerframes. Maar, aldus Lakoff, al te veel valt daarvan niet te verwachten.

Figuur 1. Beleids- en burgerframes.

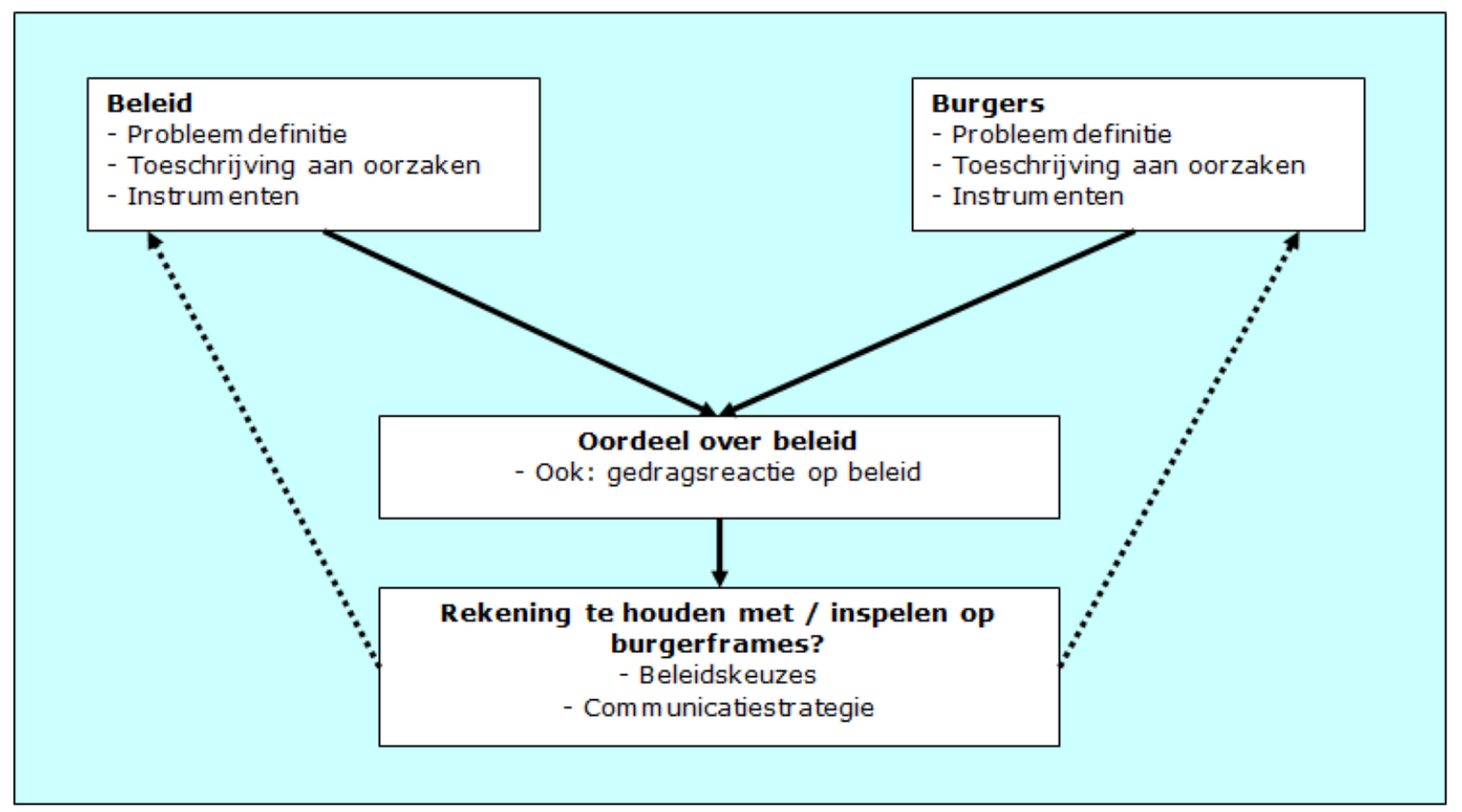

\section{TOEPASSING OP VERTROUWEN IN DE RECHTSPRAAK}

We passen het hiervoor geschetste denkschema toe op het onderwerp "vertrouwen in de rechtspraak".

\subsection{Potentiële instrumenten}

Hiervoor is onderscheid gemaakt tussen sociaal vertrouwen en institutioneel vertrouwen. Bij sociaal vertrouwen gaat het dan om het gedrag van representanten van de rechtspraak, om goede bejegening en onkreukbaarheid van de rechter. Bij institutioneel vertrouwen valt te denken aan heldere en controleerbare procedures, korte doorlooptijden, onafhankelijkheid etc. Om vertrouwen te beïnvloeden moeten instrumenten hierop aangrijpen. Daarbij zullen bij sommige burgers vooral maatregelen gericht op versterking van institutioneel vertrouwen invloed hebben, terwijl bij anderen met name maatregelen ter versterking van het sociaal vertrouwen effect sorteren. 


\subsection{Burgerframes}

Zoals eerder omschreven, zijn we op zoek naar contrasterende burgerframes. Om die frames in beeld te brengen, hebben we informatie nodig van mensen die, naar verwachting, vanuit verschillende interpretatiekaders naar de rechtspraak kijken. We hebben ervoor gekozen om focusgroepen te gebruiken om die informatie te verwerven.

Omdat we op zoek zijn naar uiteenlopende burgerframes, moeten we onderscheid maken tussen verschillende typen burgers. Op grond van bestaand onderzoek weten we wel iets over de relatie tussen kenmerken van individuen en de mate van vertrouwen in de rechtspraak. ${ }^{21}$ Maar dat zegt nog weinig over frames. We zien geen goede aanknopingspunten om te bepalen wat "de beste" typologie is om contrasterende burgerframes in beeld te brengen. Daarom hebben we gebruik gemaakt van een bestaande typologie, waarmee in het verleden voor verschillende beleidsterreinen bruikbare contrasten in beeld zijn gebracht. ${ }^{22} \mathrm{We}$ hebben namelijk gebruik gemaakt van door SmartAgent georganiseerde focusgroepen. Aan de hand van een segmentatiemodel wordt de bevolking ingedeeld in mentaliteitstypen.

Mensen worden geordend langs twee dimensies, te weten: de psychologische dimensie introvert versus extravert en de sociologische dimensie egogericht versus groepsgericht. Op basis daarvan ontstaat de een indeling in vier typen. Daarbij gaat het om vier groepen burgers die gericht zijn op achtereenvolgens harmonie, vitaliteit, controle en bescherming,

Figuur 2. Vier mentaliteitstypen

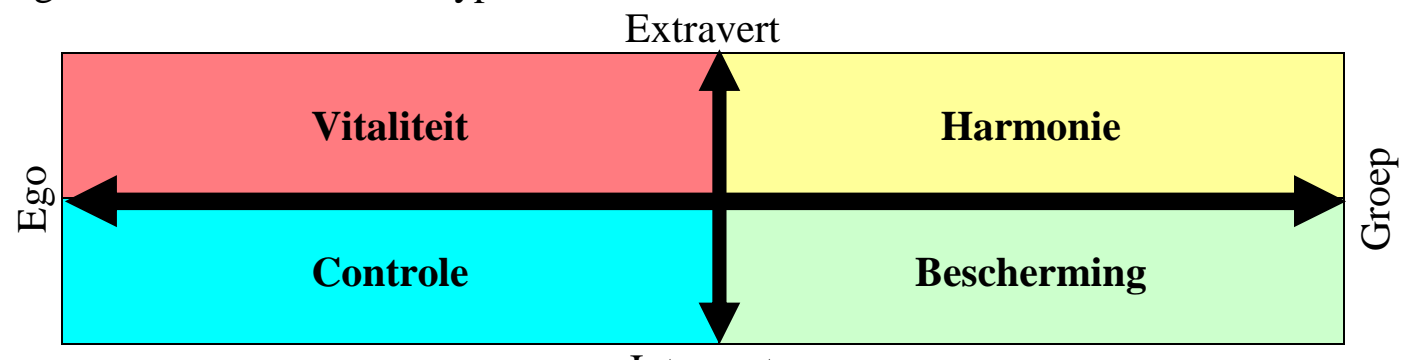

Introvert

In september 2012 vonden vier focusgroepen plaats. Aan deelnemers aan focusgroepen is de volgende vraaglijn voorgelegd:

1. Welke associaties heeft u bij "rechtspraak"?

2. In welke mate heeft $u$ vertrouwen in de rechtspraak (uitgedrukt in een rapportcijfer)? Waarom?

3. Waardoor kan het vertrouwen dat $\mathrm{u}$ in de rechtspraak heeft worden versterkt? En waardoor zou het kunnen worden aangetast?

4. Waar liggen aangrijpingspunten voor het borgen en versterken van vertrouwen?

Aan de focusgroepen namen steeds ca. 8 personen deel. De gesprekken leveren inzicht in vier contrasterende frames. ${ }^{23}$

Kijkend naar de antwoorden van de deelnemers aan de focusgroepen, zien we vier duidelijk verschillende verhalen over vertrouwen in de rechtspraak. Waarin de vier groepen sterk overeenkomen, is dat ze bij uitspraken over vertrouwen primair denken aan strafrecht. ${ }^{24}$

\footnotetext{
$21 \quad$ Achterberg \& Mascini 2013.

$22 \quad$ Reitsma 2012.

23 Wellicht ten overvloede merken we op dat de frames niet kunnen worden geïnterpreteerd als " $25 \%$ van de bevolking denkt zo".

$24 \quad$ Vgl. Van den Bos \& Brenninkmeijer 2012.
} 
Maar de factoren die bepalend zijn voor het vertrouwen, en daarmee de aangrijpingspunten voor het borgen en versterken van vertrouwen, lopen uiteen.

- De personen in de groep "rechtsboven" laten zich kennen als "sociale burgers". Ze hechten vooral aan goede en eerlijke bejegening door actoren die, in ruime zin, betrokken zijn bij de rechtspraak.

- De personen in de groep "linksboven" zijn vooral "zelfverzekerde burgers". Zij willen de ruimte hebben om zich te ontplooien en willen niet gehinderd worden door zich in nevelen hullende magistraten.

- De personen in de groep "linksonder" presenteren zich als "zakelijke burgers". Zij willen vooral een moderne en efficiënte rechtspraak.

- De personen "rechtsonder" manifesteren zich vooral als "strikte burgers". Ze willen zekerheid over waar ze aan toe zijn en willen daarom dat de rechtspraak als onafhankelijk systeem functioneert.

Voor de "zelfverzekerden" en de "socialen" is het gedrag, de opstelling en de taal van actoren van groot belang. ${ }^{25}$ Daarbij kijken de socialen overigens wel naar een bredere verzameling actoren en daarbij hoort nadrukkelijk ook de politie. De zelfverzekerden denken vooral aan rechters. Voor de "zakelijken" en de "strikten" ligt juist een grotere nadruk op het functioneren van het systeem in termen van snelheid en onafhankelijkheid etc. ${ }^{26}$ Daarbij leggen ze wel verschillende accenten. Zo zijn de zakelijken meer van de snelheid en de strikten meer van de onafhankelijkheid.

Figuur 3 geeft een samenvattend overzicht van de antwoorden op de gestelde vragen.

25 In termen van het in par. 2.1 gemaakt onderscheid, gaat het bij de sociale en de zelfverzekerde burgers dus primair om sociaal vertrouwen.

26 Bij de zakelijke en strikte burgers gaar het dus vooral om institutioneel vertrouwen. 


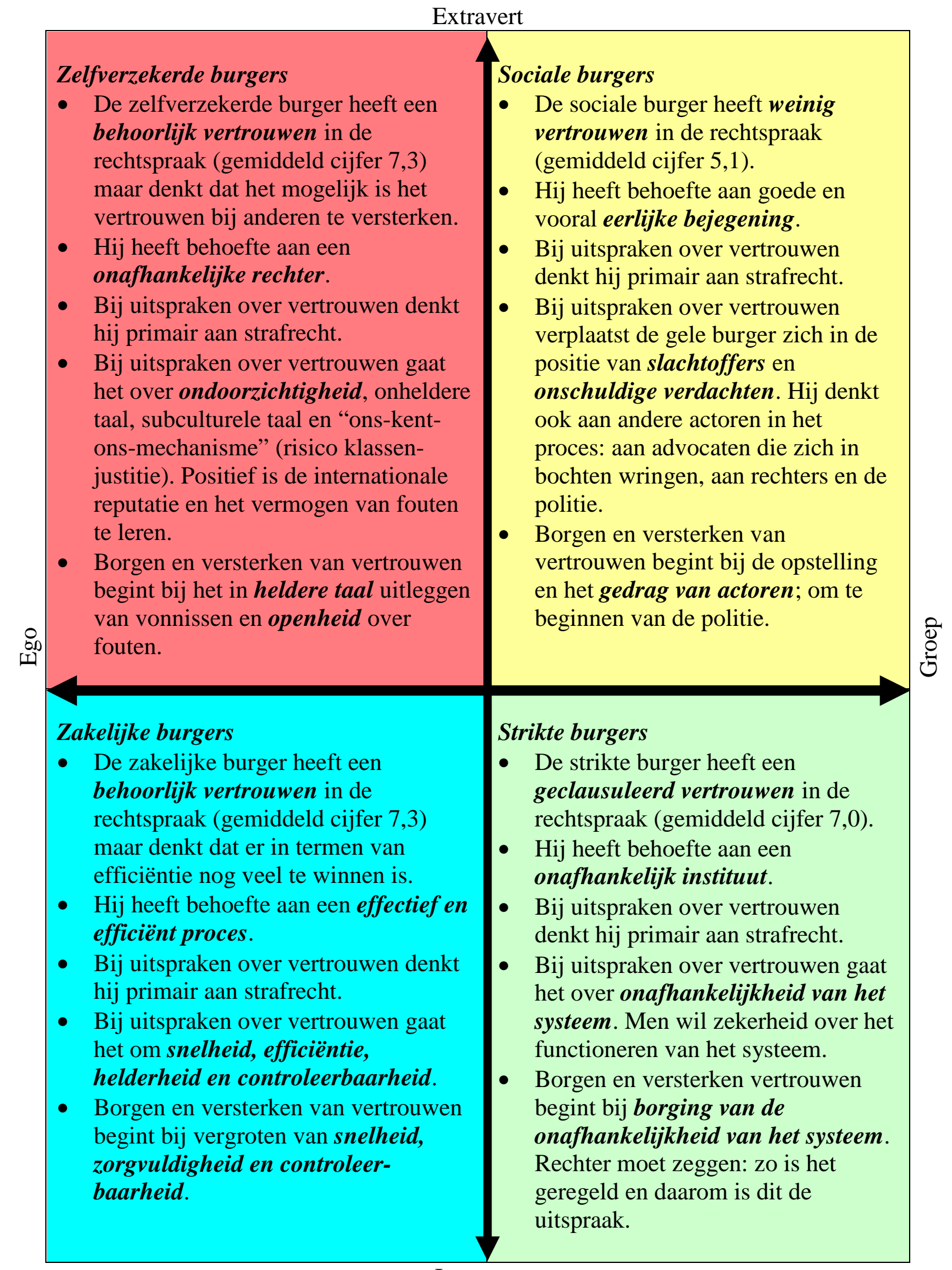

Introvert 


\subsection{Intermezzo: Frames van opinieleiders}

De focusgroepen leveren een beeld van contrasterende burgerframes, van verschillen in interpretatiekaders die "gewone burgers" hanteren. Het zijn overigens niet alleen "gewone burgers" die zich bij uitspraken over de rechtspraak laten leiden door hun frame. Dat geldt evenzeer voor mensen die beroepsmatig bij de rechtspraak betrokken zijn. Zo is recent onderzoek gedaan naar beelden die bij "beslissers" en "publieke opinieleiders" over de rechtspraak bestaan. "Reputaties gewogen" doet daarvan verslag. ${ }^{27}$ Een algemene bevinding is dat onafhankelijkheid, onpartijdigheid en integriteit als de belangrijkste kernwaarden van de rechtspraak worden gezien. Toch zijn er ook belangrijke verschillen in opvattingen te zien. Uiteenlopende uitspraken zijn goed te plaatsen in de onderscheiden burgerframes. Figuur 4 geeft een overzicht.

Uitspraken die goed passen bij het sociale burgerframe benadrukken het belang van respectvolle bejegening. Bij het strikte burgerframe past een accent op de stabiliteit en onafhankelijkheid van het systeem. Consistent met het zakelijke burgerframe is een pleidooi voor een snel en modern systeem. In overeenstemming met het zelfverzekerde burgerframe is een roep om heldere verantwoording.

Overigens zijn niet alle uitspraken van de geïnterviewde "beslissers" en "publieke opinieleiders" goed in de onderscheiden burgerframes te plaatsen. Een voorbeeld van een dergelijke uitspraak is: "Mijn beeld van de rechtspraak is dat het vooral een arrogant zootje is. Ik heb er een slecht beeld van. Veel te vaak denk ik, wat gebeurt hier voor malligheid...". 28 


\section{Extravert}

\section{Heldere verantwoording}

- "Meer maatschappelijke verantwoording is belangrijk: wachttijden, transparantie over de werkwijze, daar valt een hoop verbetering te halen" (p. 32)

- "Ik vind dat in een grote stad een rechtbank moet zijn, het moet zichtbaar voor de burgers zijn. Ik ben heel enthousiast over de rijdende rechter, ik denk dat het heel goed is als burgers zien hoe de afweging wordt gemaakt." (p. 32)

- Weten hoe communiceren werkt, zoek maar je eigen Robbert Dijkgraaf, die het prima kan uitleggen. Zo iemand is denk ik een antwoord: hij is authentiek, heeft gezag, is van deze tijd, en spreekt aan buiten zijn peergroup." (p. 41)
Respectvolle bejegening

- "De ervaring bij procespartijen is erg afhankelijk van hoe een zitting is verlopen. Komen ze goed aan het woord, zijn ze gerespecteerd, hebben ze hun zegje kunnen doen?" (p. 35)

- "De burgers stellen hoge eisen aan de rechtspraak. Ze willen respectvol bejegend worden. Dan kan het niet als ze het gevoel krijgen dat de rechter niet luistert, of dat het te lang duurt of dat ze na lang wachten naar mediation worden gestuurd." (p. 35)
Snel en modern

- "Dat bepaalde zaken gemiddeld tien jaar kunnen duren. (...) In elke stap wordt het uitgeprint, gedigitaliseerd, aangebracht bij de volgende stap, uitprinten, digitaliseren. Dat gebeurt echt. Het wordt vijf keer uitgeprint en gelezen en gedigitaliseerd". (p. 28)

- "Een groot minpunt is de lange doorlooptijd. (...) er kan veel meer digitaal dan nu". (p. 28)

- "Het duurt alleen veel te lang, het duurt véél te lang. Daar moet men echt over zijn eigen schaduw heen stappen" (p. 28)

- "Eindeloos traag, rampzalig dat stukken kwijt zijn, dat je tig keer moet bellen met de griffie". (p. 28)

- "Tegenwoordig wordt bij elke bushalte aangegeven hoe lang je nog moet wachten, maar bij de rechtspraak... Dat is gewoon slecht management”. (p. 35)

- "Ik ben verbaasd over hoe ouderwets het in de rechtspraak eraan toe gaat. Volgens mij kan veel meer digitaal dan nu gebeurt. Die slag moeten rechtbanken maken." (p. $35)$.

\section{Stabiliteit en onafhankelijkheid}

- "Het systeem als zodanig zit in de problemen. Je hebt schepen die onder water stabilisatoren hebben. Dit land, en de rechterlijke macht en het openbaar bestuur in het algemeen, varen momenteel zonder stabilisatoren". (p. 31)

- "Een mate van onverstoorbaarheid is van belang. Ik vind het enigszins zorgwekkend als de rechterlijke macht zich zorgen maakt over wat voor beeld ze in de media neerzetten. Het beïnvloedt het onafhankelijk oordeel. Ik vind het juist goed als het volk over de rechtspraak heen komt en het niet eens is met de uitspraak". (p. 31) 


\subsection{Omgaan met verschillende burgerframes}

De vorige paragraaf laat zien dat uitspraken van opinieleiders in verschillende frames te plaatsen zijn. ${ }^{29}$ Voor het doel van dit artikel zijn echter vooral de burgerframes relevant. We zien vier duidelijk onderscheiden "verhalen" over vertrouwen in de rechtspraak. Die verhalen bieden aanknopingspunten voor wie op zoek is naar mogelijkheden om het vertrouwen in de rechtspraak te borgen of te bevorderen. In de kern komen die aanknopingspunten op het volgende neer:

- Sociale burger: eerlijke bejegening door actoren in de strafrechtelijke keten.

- Zelfverzekerde burger: helder communicerende, onafhankelijke rechter.

- Zakelijke burger: effectief en efficiënt proces.

- Strikte burger: onafhankelijkheid van het instituut.

De aanknopingspunten lopen nogal uiteen. Sterker, er bestaan spanningen tussen. De sociale burger wil van het begin tot het eind begripvol benaderd worden. De zakelijke burger zal dit al snel als pamperen ervaren en dat valt daar niet zo goed. Ook de behoeften van de sociale en de strikte burger lijken moeilijk te verenigen. De behoefte aan begrip en nabijheid van de sociale burger, verhoudt zich moeilijk tot het belang dat de strikte burger hecht aan onafhankelijkheid. Onafhankelijkheid vergt immers een zekere onthechtheid en afstand. Wie op zoek is naar mogelijkheden om vertrouwen in de rechtspraak te bevorderen, loopt hier tegen dilemma's op. Immers, maatregelen die volgens het ene frame helpen om vertrouwen te versterken doen dat volgens een andere frame juist niet. De vraag dringt zich op of een zekere segmentatie wenselijk en mogelijk is. Dat wil zeggen: zijn er mogelijkheden om maatregelen te richten op specifieke groepen om zo het vertrouwen bij groepen met uiteenlopende frames te versterken?

Voor alle vier de groepen is communicatie een belangrijk punt. Maar er bestaan wel flinke verschillen ten aanzien van de vraag welke communicatie geschikt is voor het borgen en versterken van vertrouwen in de rechtspraak.

- Voor "de" sociale burger gaat het ook om goed luisteren, of ruimer: goed bejegenen, van partijen. En dat begint nadrukkelijk al bij de politie.

- Voor "de" strikte burger moet de rechter nadrukkelijker naar buiten treden. Ze moeten duidelijk maken dat ook voor de rechter het recht een gegeven is. Indien een uitspraak niet bevalt, kijk dan naar de wetgever en niet naar de rechter.

- Voor "de" zakelijke burger staat communicatie in het teken van de controleerbaarheid.

- Voor "de" zelfverzekerde burger gaat het bij communicatie vooral om openheid en taalgebruik. Leg in heldere taal uit waarom een uitspraak is zoals die is.

Hier gaat het om framing in de betekenis van het vinden van een taal die past bij het frame van de desbetreffende groep.

\section{BESLUIT}

Het vertrouwen in de rechter staat ter discussie. Aansluitend bij die discussie, hebben we in dit artikel gekeken naar mogelijkheden om vertrouwen in de rechtspraak te versterken. We hebben geconstateerd dat het niet veel zin heeft om te spreken over het vertrouwen van de burger. Daarvoor zijn de verschillen tussen burgers te groot.

Gebruikmakend van focusgroepen, hebben we contrasterende burgerframes in beeld gebracht. Die frames maken het mogelijk om te toetsen hoe maatregelen bij de desbetreffende

29 Dit doet de vraag rijzen of die opinieleiders verwoorden wat groepen burgers denken of dat groepen burgers gaan denken wat opinieleiders verwoorden. Die vraag laten we hier echter rusten. 
groepen uitwerken. Wat problematisch is, is dat maatregelen die bij de ene groep leiden tot een versterking van vertrouwen bij een andere groep juist afbreuk aan vertrouwen kan doen. Zo is er enerzijds een groep burgers die vooral behoefte heeft aan goede bejegening en anderzijds een groep die vooral behoefte heeft aan een effectief en efficiënt systeem. In feite gaat het om groepen met uiteenlopende waardenoriëntaties, waarbij het wel haast onmogelijk lijkt om aan beide tegemoet te komen. En daarmee lijken beleidsmakers voor een dilemma te staan. Trompenaars en Hampden-Turner hebben een oplossing gesuggereerd voor dergelijke dilemma's. Door te differentiëren naar doelgroep is het mogelijk aan beide waardenoriëntaties tegemoet te komen. ${ }^{30}$

We sluiten af met enkele relativerende opmerkingen. De eerste is dat we in dit artikel het belang van frames hebben benadrukt. Maar het is natuurlijk niet zo dat frames volledig bepalend zijn voor het vertrouwen dat burgers in de rechtspraak hebben. Vertrouwen is een functie van signalen en frames. Een frame is immers een interpretatiekader waardoor signalen betekenis krijgen. Berichten over de bejegening van verdachten, gerechtelijke dwalingen, doorlooptijden en procedurefouten werken via frames door in het vertrouwen dat burgers in de rechtspraak hebben. De tweede relativerende opmerking betreft de relatie tussen vertrouwen in de rechtspraak en institutioneel vertrouwen. In de praktijk beweegt vertrouwen in de rechtspraak beweegt mee met institutioneel vertrouwen. Maar de correlatie is niet perfect. Een implicatie is dat geen wonderen moeten worden verwacht van maatregelen die specifiek zijn gericht op het versterken van vertrouwen in de rechtspraak.

30 Expertisecentrum rechtshandhaving 2005, p. 29. Trompenaars \& Hampden-Turner 2006. In deze redeneerlijn past bijvoorbeeld ook de gedachte dat de effectiviteit van handhavingsstijlen afhankelijke is van de doelgroep, zodat differentiatie naar doelgroep de effectiviteit van de handhaving kan bevorderen. Vgl. Couvret \& Mulder 2008. 


\section{LITERATUUR}

Achterberg, P. \& P. Mascini, 'Kenmerken Nederlanders die de rechtspraak wantrouwen zich door institutioneel wantrouwen in het algemeen?', $N J B$, 2013, pp. 671-677.

Beugelsdijk, S., 'A note on the theory and measurement of trust in explaining differences in economic growth', Cambridge Journal of Economics, 2006-30, pp. 371-387.

Benford, R.D. \& D.A. Snow, 'Framing processes and social movements: an overview and assessment', Annual Review of Sociology, 2000-26, pp. 611-639

Bos, K. van den, Vertrouwen in de overheid: wanneer hebben burgers het, wanneer hebben ze het niet, en wanneer weten ze niet of de overheid te vertrouwen is?, Utrecht: Universiteit Utrecht (essay), 2011.

Bos, K., van den \& A.F.M. Brenninkmeijer, 'Vertrouwen in wetgeving, de overheid en de rechtspraak', $N J B, 2012$, pp. 1451-1457.

Brenninkmeijer, A.F.M., K. van den Bos \& E. Röell, 'Procedurele Rechtvaardigheid.' Rechtsgeleerd Magazijn Themis, 2012-4, pp. 178-181.

Brink, G. van den, Geloofwaardige rechtspraak: de rechter als bruggenbouwer, Den Haag: Raad voor de rechtspraak (rechtspraaklezing), 2008.

Broeders, D. c.s. (red.), Speelruimte voor transparantere rechtspraak, WRR-Verkenning 26, 2013

Bruijn, H. de, Geert Wilders in debat: over framing en reframing van een politieke boodschap, Lemma, 2010.

Bruijn, H. de, Framing: Over de macht van taal in de politiek, Altas, 2011.

Chong, D. \& J.N. Druckman, 'Framing Theory', Annual Review of Political Science, 200710, pp. 103-126.

Couvret, E. \& S. Mulder, Stijlkeuzes in de handhaving: De rol van waarden bij burgers en bedrijven voor de keuze in handhavingsstijl, Boom, 2008.

Dekker, P., T. van der Meer \& E. Steenvoorden, Continu Onderzoek Burgerperspectieven 2008|3, SCP.

Dekker, P. \& H. Posthumus, Continu Onderzoek Burgerperspectieven 2013|1, SCP.

Dekker, P. \& T. van der Meer, Vertrouwen in de rechtspraak nader onderzocht, Den Haag: Sociaal en Cultureel Planbureau, 2007.

Expertisecentrum rechtshandhaving, Laveren tussen Scylla en Charybdis: over de toekomst van handhaving, Ministerie van Justitie, 2005. 
Frissen, P., P. 't Hart \& S. Sieckelinck, Reputaties gewogen. Beelden over de rechtspraak bij beslissers en publieke opinieleiders, Raad voor de rechtspraak, 2012.

Fukuyama, F., Trust: The Social Virtues and The Creation of Prosperity, 1995.

Goffman, E., Frame Analysis: an essay on the organization of experience, Northeastern University Press, 1974.

Heijden, K. van der, Scenarios: The Art of Strategic Conversation, Chichester: Wiley, 2005, $2^{\text {nd }}$ Edition.

Hertogh, M., 'Wat weten en vinden burgers van recht?' In: M. Hertogh \& H. Weyers (red.), Recht van onderop, Ars Aequi Libri, Nijmegen 2011, pp. 287-300.

Lakoff, G., Don't think of an elephant!, Chelsea Green, 2004.

Lakoff, G., The political mind, Penguin Books, 2008.

Lakoff, G. \& E. Wehling, The little blue book, Free Press, 2012.

Letterie, W. \& O.H. Swank, 'Economic policy, model uncertainty and elections', Economics and Politics, 1998-10, pp. 85-103.

Luhmann, N., Trust and power, Chichester, Wiley, 1979.

Meer, T. van der, 'Vertrouwen in de rechtspraak: empirische bevindingen', Rechtstreeks, 2004, nr.1.

Nekkers, J., Wijzer in de toekomst, Business contact, 2007.

Reitsma, D., Bestuurders: “Begrijpen wij elkaar?”, 2012.

Ridder, J. den, J. Kullberg \& P. Dekker, Continu Onderzoek Burgerperspectieven 2011|4, SCP.

Ruijter, P. de, S. Stolk \& H. Alkema, Klaar om te wenden, Schiedam: Scriptum 2011.

Scearce, D. \& K. Fulton, What if? The art of scenario thinking for nonprofits, Global Business network, 2004.

Sztompka, P., Trust: A Sociological Theory, Cambridge: Cambridge University Press, 1999.

Thibaut, J. \& I. Walker, Procedural Justice: a psychological analysis, Hillsdale: Erlbaum 1975.

Trompenaars, F. \& C. Hampden-Turner, Over de grenzen van cultuur en management, Uitgeverij Business Contact, 2006.

Tyler, T.R., Why people obey the law, Yale: Yale University Press, 1990. 
Velthoven, B.C.J. van, 'Economische groei en institutionele context', Recht der Werkelijkheid, 2005-26 (2), pp. 27-57.

Wetenschappelijke Raad voor het Regeringsbeleid (WRR), De toekomst van de nationale rechtsstaat, Den Haag: Sdu Uitgevers, 2002. 